\title{
Hepatitis $C$ compensation may be extended
}

A longer version of this article was posted Nov. 22, 2004, at www.cmaj.ca/news/22_11_04.shtml

Six years after the original agreement to compensate some Canadians who contracted hepatitis $\mathrm{C}$ from tainted blood, the federal government has agreed to begin negotiations to pay other victims who contracted the disease before 1986 and after 1990 .

The decision to begin talks with officials and legal counsel for the estimated 5000 to 6000 victims was linked to new information now available to the government, Health Minister Ujjal Dosanjh said.

"A number of circumstances have changed since the original compensation decision was taken in 1998," stated Dosanjh. "We have therefore decided that it is right and responsible to revisit the decision and begin discussions on options for financial compensation to those who were infected through the blood supply before 1986 and after 1990."

After the release of the 1997 Justice Horace Krever Commission's report into Canada's blood system, the government established 2 classes of hepatitis $\mathrm{C}$ victims. Ottawa acknowledged responsibility for those infected from 1986 to 1990 and established a \$1.2-billion trust fund for them. Anyone infected before 1986 or after 1990 was excluded on the grounds that protective measures were unavailable before 1986 to detect blood supply problems. After 1990 , the government said, protective measures were in place.

The original decision to exclude those victims caused dissension in the Liberal ranks. Many MPs insisted that everyone infected through the tainted blood supply should be compensated. $\checkmark$ When then-prime minister Jean Chrétien declared the vote a question of confidence in the government, several Liberal MPs were reduced to tears in the House of Commons. But none voted against the bill, even as Opposition members cried "Shame!"
The fight for compensation for excluded victims recently gained momentum when it was revealed that other jurisdictions were taking preventive measures to screen for hepatitis $\mathrm{C}$ before 1986, and as it became increasingly apparent that the total number of hepatitis $C$ victims had been overestimated.

Claimants fall into 3 categories: those primarily infected, those secondarily infected and family members who bore consequences such as loss of financial support. As of Sept. 30, 2004, the trust fund had paid out about \$388 million on 9424 approved claims. In 1998 it was estimated that up to 14900 persons infected between Jan. 1, 1986, and July 1, 1990, would file claims.

Improvements in treatment may be one reason the estimates were off. According Health Canada, current treatment with interferon is resulting in viral clearance for some people. Many of these individuals are not claiming increased compensation from the fund.

All of this opened up the possibility of using the trust fund to help the "forgotten" victims.

In an interview with $C M A \mathcal{A}$, Dosanjh outlined a time frame for government and lawyers of the victims to settle. If met, it could resolve one of the most heated dimensions of the hepatitis C file by June 2005.

In a previous response to their plight, Ottawa set aside $\$ 300$ million over 20 years for the provinces to cover services such as drug therapy for the pre-1986, post-1990 victims. As far as anyone has been able to determine, the provincial funds appear to have simply gone into the general health care revenue for hepatitis $\mathrm{C}$ treatment.

The result has been extensivemedia coverage of ailing victims struggling with serious financial pressures due to unemployment and expensive medications.

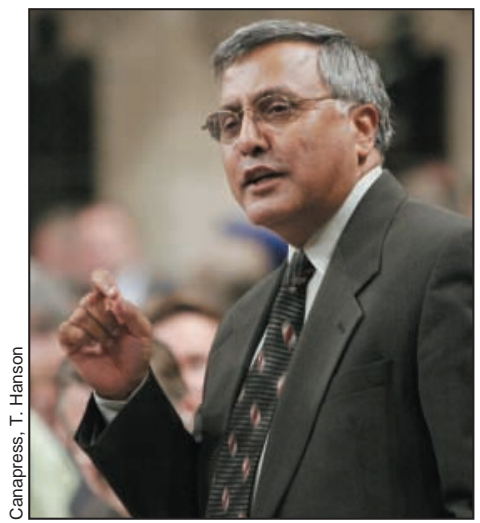

Dosanjh: Things have changed since the initial compensation.

Toronto lawyer David Harvey, who represents about 3500 pre-1986, post-1990 victims across Canada, says the original 5-year-old trust fund currently stands at about $\$ 1.1$ billion, since it has grown over the years with interest. "It will be pretty obvious once they have done the number crunching that there is more than enough money to compensate everyone," he says.

Dosanjh acknowledged the possibility of an actuarial surplus in the fund, though how much has to be determined by the court because the fund has to last another 70 years. Harvey also represents the victims in 1 of 3 class action lawsuits under way. The others are in Quebec, with about 600 victims, and $\mathrm{BC}$, with about 900 .

Harvey wants everyone infected through tainted blood to be compensated equally and for the money to be made available as soon as possible. "I get calls from people who cannot afford treatment, [and] are on the verge of losing their houses," he says. "They are sick and in desperate financial straits. They need money now."

Dosanjh says he realizes that asking victims to wait until June is difficult. "I appreciate that," he said. "I wish I could give you a different answer." - Pauline Comeau, Ottawa 